\title{
The Effects of School Principals' Managerial Competence and Job Motivation on Teacher Efficiency
}

\author{
Andri Wahyono $^{1 *}$, Happy Fitria ${ }^{2}$, Achmad Wahidy $^{2}$ \\ ${ }^{1}$ SMA Negeri 5 Palembang, Indonesia \\ ${ }^{2}$ Universitas PGRI Palembang, Indonesia \\ *Email: andriwahyono73@gmail.com
}

\begin{abstract}
The purpose of this research is to investigate the influence of principal managerial competence and job motivation on teacher performance at SMA Negeri 5 Palembang. This thesis is an observational research that employs a quantitative approach and includes 72 study participants. This study used an ex post facto research design. The instrument test in this study used validity and reliability tests using the SPSS version 15 software application with the Cronbach's Alpha method so that data analysis was easier and more practical. Depending on the findings of the study, it is reasonable to state that; 1) principal managerial competence affects teacher performance in SMA Negeri 5 Palembang by $43.0 \% ; 2$ ) work motivation affects teacher performance at SMA Negeri 5 Palembang by $31.4 \%$, and 3) principal managerial ability and encouragement at work affects teacher performance at SMA Negeri 5 Palembang $65.7 \%$.
\end{abstract}

Keywords: Competence in Management, Motivation at Work, Performance as a Teacher

\section{INTRODUCTION}

Efforts to produce quality schools are based on the many factors involved in it. One of the most decisive roles is the principal as the leader of the educational institution. The leader, as the highest person with the most influence and power over the school's success, must have administrative skills. A good principal must be able to aim to enhance teacher results.

The school principal coordinates, supervises, directs and assesses various school activities that are being implemented. One of the managerial functions performed by the principal is the supervisory function, also known as the control function. The principal is effective if he recognizes the school's life as a dynamic and unique entity and is capable of carrying out the role of school leader [1].

At least the principal has the roles and functions of Educator, Manager, Administrator, Supervisor, Leader, Innovator and Motivator (EMASLIM). As, a school manager, the principal has a very important role, given his position structurally as a formal legal leader who has full power in the institution he leads. Principals are required to have managerial competence in order to have a concept in leading the school.

While performing the tasks and duties as educational leaders, the principal coordinates, supervises, directs and assesses various school activities that are being carried out. One of the managerial functions performed by the
Principal is the supervisory function or also known as the control function. In accordance with its essence, the supervisory activities carried out by the Principal are activities to clearly identify what results are expected in planning as well as irregularities that occur in the implementation of school programs. Emphasized that the leadership of the principal has a major impact on the standards and standard of teachers in schools [2]. The school principal is responsible for the effectiveness and effectiveness of the education provider in his school as manager of the education unit / school. Principals have a wide variety of occupations, including chair, administrator, advisor, assistant, and group liaison. Principals must be able to build a collaborative atmosphere in which workers exchange skills and commit to improving the quality of schools and teaching. It appears that operational activities are contained in the essence of supervision, namely quality. Teacher quality is the result of the work of all the activities of all existing resource components. Productivity is an action or reaction that produces results in relation to what they do when faced with a challenge [3].

The principal must also have high knowledge and skills, which are in line with the school's area of responsibility. As a result, he will fulfill his position as an effective organizational leader. Additionally, they must also have creative ideas that can improve school development. With the help of the teachers, he can discuss these ideas to be applied to the school. If an 
agreement is reached between the principal and the teacher, these ideas can be realized [4].

Which states that the role of the principal as managerial, among others, can overcome conflicts that occur between teachers and must be neutral and objective and always motivate teachers to focus on improving their competence and on tasks and responsibility in school.

This has not been seen in real terms at SMA Negeri 5 Palembang, where the principal is still not intense in motivating teachers to carry out their daily duties. So, it is only natural that there are still teachers who are not so motivated. Generally, they come to school only to carry out their obligations.to teach their students according to a predetermined teaching schedule, then go home without too much interaction with the principal or other school members. This happens because the Principal has not been intensively communicating with the teachers, specifically, addressing teacher issues in fulfilling its responsibilities as teachers. This lack of communication makes educators feel reluctant to reveal essential things regarding their teaching complaints. This has an impact on teachers' work motivation that is not optimal due to the lack of attention of the principal on what the teacher is doing.

Teacher work motivation is one of the factors that encourages a teacher to carry out his job with enthusiasm so that he will get better performance results. The teacher will demonstrate an interest in carrying out a task or event and then do it well if there is a motivating force, namely motivation [5]. In the world of work in all fields including education, motivation has a very important role, a person will work more actively and diligently if he has high motivation in himself. A worker is a component member of a work organization who plays an important role. Workplace organization has a huge impact on a person's motivation. Quality human resources, among others, are shown by high performance and productivity. To improve teacher performance professionalism is needed. Professional teachers have the ability to continuously perform professionalism such as self-evaluation, selfmotivation, self-discipline, and self-development [6]. All of that cannot be separated from the role of a leader, namely the Head of the School.

Paying attention to the dimensions of teacher work motivation mentioned above, it feels very important because their performance is influenced by their mental condition, and vice versa, the soul influences them in teaching. This is in accordance with what has been outlined in Law Number 14 of 2005 concerning Teachers and Lecturers.

Law Number 14 of 2005 concerning Teachers and Lecturers explains that every teacher must have 4 (four) competencies in carrying out their daily duties, which include pedagogical competence, professional competence, social competence, and personality competence. can certainly be a reflection of their competence and their basic motivation as teaching staff (educators). Teacher professionalism is closely related to the ability to realize or actualize the competencies required for every teacher. Competence is a specification of the knowledge, skills and attitudes a person has and their application in work in accordance with the performance standards required by the field. Competence will be manifested in the form of mastery of knowledge, skills and professional attitudes in carrying out their duties [7]. Teachers who have the four competencies above will have implications for their performance. The better the competencies possessed by the teacher, the better and their performance will increase. The ability of the teacher to elicit students' interest in learning is the first stage of a meaningful learning process. As a result, students will be more involved and inspired to improve all of their skills in the classroom [8].

Paying attention to the dimensions of teacher work motivation mentioned above, it feels very important because their performance is influenced by their mental condition, and vice versa, the soul influences them in teaching. This is in compliance with the provisions of Law No. 14 of 2005 on Teachers and Lecturers.

According to Law No. 14 of 2005 Regarding Educators and Instructors, every teacher also had four competencies in order to carry out their daily duties, that included pedagogical, competence, professional competence, social competence, and personality competence, can certainly be a reflection of their competence and their basic motivation as teaching staff (educators). Teacher professionalism is closely related to the ability to realize or actualize the competencies required for every teacher. Competence is a description of a person's experience, abilities, and attitudes, as well as their application in the workplace in compliance with the performance requirements demanded by the field. Competence can be demonstrated by mastery of expertise, skills, and professional attitudes in the performance of their duties. Teachers who have the four competencies above will have implications for their performance. The better the competencies possessed by the teacher, the better and their performance will increase.

Teacher performance is determined by various factors, in addition to the four competencies above that must be possessed, also due to the work environment including the principal's ability to influence or encourage other teachers to work voluntarily to achieve certain goals or objectives in certain situations. The ability of the principal to inspire teachers to work would have an impact on increasing teacher job productivity which in turn has implications for improving teacher performance in carrying out their daily jobs as a teacher in schools, considering the educator quality is the achievement of a teacher in realizing his role as a teacher.

The conditions that occurred in SMA Negeri 5 Palembang were not as expected, communication between the principal and teachers was still very minimal, this was due to the inadequacy of the policies issued. The policies taken by the Principal are sometimes 
not in line with the applicable provisions or policies because they are issued without an in-depth and systematic study so that there are often conflicts among teachers. Not to mention the problem of the principal's appreciation of what the teacher has done. This triggers a decrease in teacher motivation so that it has an impact on teacher performance. The presence of a leader in an organization is very necessary in achieving goals because the leader is the driving force for implementing the goals of the organization. In the task of moving includes activities: giving directions, guiding, educating, fostering, directing, and so on [7].

Depending on the above definition, the authors wish to conduct analysis, evaluate, and explain the effect of the principal's managerial competence and job motivation on the quality of teachers at SMA Negeri 5 Palembang.

\section{METHODS}

This study employs quantitative analysis. In this study using descriptive correlative research type, there is a relationship between the variables indicated by the correlation coefficient. This type was chosen because this study aims to reveal how much influence the two variables, namely, principal managerial competence, job motivation on the dependent variable, namely teacher efficiency.

This study has one dependent variable and two independent variables. In this analysis, the dependent

variable is teacher efficiency, denoted as $\mathrm{Y}$. The independent variable is principal managerial competence, denoted by $\mathrm{X}_{1}$, and job motivation, denoted by $X_{2}$. The relation between the two independent variables and the dependent variable.

This study was carried out at SMA Negeri 5 Palembang. According to information collected from the head of the School Administration Personnel (TAS), the total number of teachers at SMA Negeri 5 Palembang is 72. The study will take place between July and October of 2020 .

\section{RESULTS AND DISCUSSION}

\section{a. Principal Managerial Competencies}

Based on the table below, the first null hypothesis testing is rejected based on the $t$ significance value obtained in the principal managerial competence variable is 0.003 so that this value can be stated to be smaller than the predetermined $\alpha$ probability of 0.05 . Thus, the Sig.t value is $0.003<0.05$, thus indicating a rejection of $\mathrm{H}_{0}$ and acceptance of $\mathrm{H}_{1}$. The acceptance of $\mathrm{H}_{1}$ means that the principal's managerial, competence affects, the performance of teachers at SMA Negeri 5 Palembang.

The second hypothesis test results indicate acceptance of $\mathrm{H}_{1}$.

Table 1.

Hypothesis Test Results Partially

\begin{tabular}{|c|c|c|c|c|}
\hline No & $\begin{array}{c}\text { Zero Hypothesis }\left(\mathrm{H}_{0}\right) \text { and } \\
\text { Alternative Hypothesis }(\mathrm{H1})\end{array}$ & Data & Value & Conclusion \\
\hline 1 & $\begin{array}{l}\mathrm{H}_{0:} \text { There is no significant effect of Principal } \\
\text { Managerial Competencies on teacher } \\
\text { performance at SMA Negeri } 5 \\
\text { Palembang } \\
\mathrm{H} 1: \quad \begin{array}{l}\text { There is a significant positive effect of } \\
\text { Principal Managerial Competencies on } \\
\text { teacher performance at SMA Negeri } 5\end{array}\end{array}$ & $\begin{array}{l}\mathrm{T}_{\text {count }}=0,970 \\
\mathrm{t}_{\text {table }}(72 ; \\
0,05)=1,667 \\
\text { Probability } \\
(\text { Sig. })=0,003\end{array}$ & $\begin{array}{c}\text { Prob }< \\
0,05 \\
\mathrm{~T}_{\text {cout }}>\mathrm{T}_{\mathrm{t}} \\
\text { able }\end{array}$ & $\begin{array}{l}\mathrm{H}_{0} \\
\text { rejected } \\
\mathrm{H}_{1} \\
\text { accepted }\end{array}$ \\
\hline
\end{tabular}

\section{b. Teacher Work Motivation}

Based on the table below, the first null hypothesis testing is rejected based on the $\mathrm{t}$ significance value obtained in the principal managerial competence variable is 0.003 so that this value can be stated to be smaller than the predetermined $\alpha$ probability of 0.05 . Thus, the Sig.t value is $0.003<0.05$, thus indicating a rejection of $\mathrm{H} 0$ and acceptance of $\mathrm{H} 1$. The acceptance of $\mathrm{H} 1$ means that the principal's managerial competence affects the performance of teachers at SMA Negeri 5 Palembang.

From the analysis above, it shows that work motivation also plays a very important role in improving employee performance. This is in line with the results of research that there is a positive effect of work motivation on employee performance at SMK Negeri 3 Sekayu, namely $37.6 \%[8]$. 
Table 2.

Hypothesis Test Results Partially

\begin{tabular}{|c|c|c|c|c|}
\hline No & $\begin{array}{c}\text { Zero Hypothesis (H0) and } \\
\text { Alternative Hypothesis (H1) }\end{array}$ & Data & Value & Conclusion \\
\hline 2 & $\begin{array}{l}\text { There is no significant effect of teacher } \\
\text { work motivation on teacher performance } \\
\text { at SMA Negeri } 5 \text { Palembang } \\
\text { There is a significant positive effect of } \\
\text { teacher work motivation on teacher } \\
\text { performance at SMA Negeri } 5 \\
\text { Palembang }\end{array}$ & $\begin{array}{l}T_{\text {count }}=2,723 \\
\mathrm{t}_{\text {table }}(72 ; \\
0,05)=1,667 \\
\text { Probability } \\
\text { (Sig.) }=0,008\end{array}$ & $\begin{array}{c}\text { Prob }< \\
0,05 \\
\mathrm{~T}_{\text {cout }}>\mathrm{T}_{\text {ta }} \\
\text { ble }\end{array}$ & $\begin{array}{l}\mathrm{H}_{0} \\
\text { rejected } \\
\mathrm{H}_{1} \\
\text { accepted }\end{array}$ \\
\hline
\end{tabular}

\section{c. Teacher Performance}

The table above explains that the regression equation is obtained from the following formula:

$$
\begin{aligned}
& Y=a+b_{1} X_{1}+b_{2} X_{2} \\
& (Y)=-8,001+-0,340\left(X_{1}\right)+1,211\left(X_{2}\right)
\end{aligned}
$$

In the regression equation, the standard error obtained is 5.722 for beta zero. Meanwhile, the standard error of the regression equation for the principal managerial competence variable is 0.140 , and the work motivation variable is 0.149 . The significance value of the $t$ test variable for principal managerial competence is 2.439 with a Sig value of 0.017 , and the work motivation variable of 8.146 with a Sig value of 0.000 . The significance value of $\mathrm{t}$ indicates that the significance value of the managerial competence variable is smaller than the probability value set at 0.05 and the significance value of the work motivation variable is smaller than the specified probability value. Thus, it can be concluded that the principal managerial competence partially affects teacher performance as well as work motivation partially influences the performance of teachers at SMA Negeri 5 Palembang.

Table 3. Regression Analysis Results

\begin{tabular}{|c|c|c|c|c|c|c|c|c|}
\hline & \multirow{3}{*}{ Model } & $\begin{array}{r}\text { Unstand } \\
\text { Coeff }\end{array}$ & & $\begin{array}{l}\text { Standardized } \\
\text { Coefficients }\end{array}$ & \multirow{3}{*}{ t } & \multirow[b]{2}{*}{ Sig. } & \multicolumn{2}{|c|}{$\begin{array}{c}\text { Collinearity } \\
\text { Statistics }\end{array}$} \\
\hline & & & & \multirow[b]{2}{*}{ Beta } & & & \multirow[b]{2}{*}{$\begin{array}{l}\text { Tole- } \\
\text { rance }\end{array}$} & \multirow[b]{2}{*}{ VIF } \\
\hline & & B & $\begin{array}{r}\text { Std. } \\
\text { Error }\end{array}$ & & & & & \\
\hline 1 & $\begin{array}{l}\text { (Constant) } \\
\text { managerial }\end{array}$ & -8.001 & 5.722 & & -1.398 & .166 & & \\
\hline & competence & .340 & .140 & .201 & 2.439 & .017 & .616 & 1.623 \\
\hline & $\begin{array}{l}\text { work } \\
\text { motivation }\end{array}$ & 1.211 & .149 & .671 & 8.146 & .000 & .616 & 1.623 \\
\hline
\end{tabular}

Coefficients $^{\mathbf{a}}$

a. Dependent Variable: Efficiency/Performance

Table 4. Results of Analysis of Variance $\operatorname{ANOVA}(\mathbf{b})$

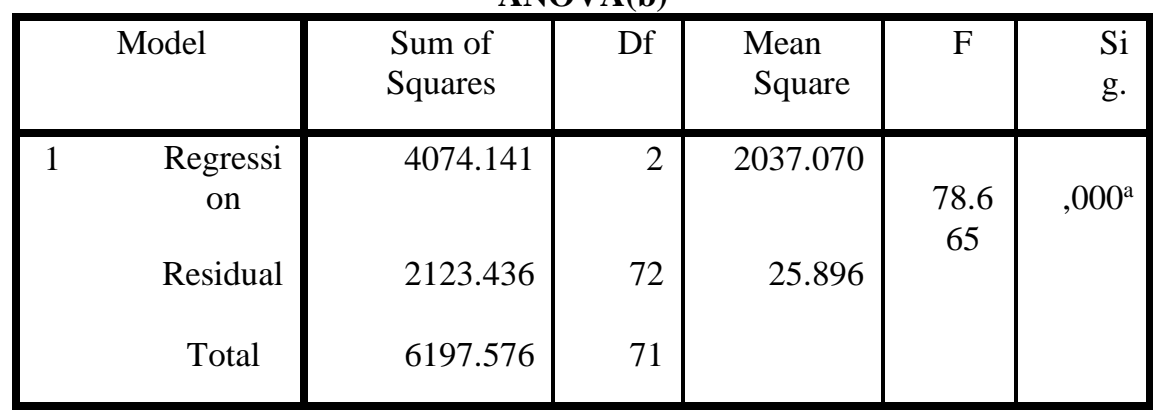


Table 5.

Result of the Coefficient of Determination Model Summary ${ }^{(\mathbf{b})}$

\begin{tabular}{crrrrr}
\hline $\begin{array}{c}\text { Mode } \\
1\end{array}$ & $\mathrm{R}$ & $\begin{array}{c}\mathrm{R} \\
\text { Square }\end{array}$ & $\begin{array}{c}\text { Adjusted R } \\
\text { Square }\end{array}$ & $\begin{array}{c}\text { Std. Error of } \\
\text { the Estimate }\end{array}$ & Durbin-Watson \\
\hline 1 & $.811^{\mathrm{a}}$ & .657 & .649 & 5.089 & 2.325
\end{tabular}

Predictors: (Constant), managerial competence, work motivation

Dependent Variable: Efficiency/Performance

The results of the correlation analysis as shown in the table above explain the regression output which shows the effect of principal managerial competence and work motivation on teacher performance, the R Square value is 0.657 . This figure shows that the variation in teacher performance scores which can be explained by the regression equation obtained is $65.7 \%$, while the remaining $34.3 \%$ is influenced by other variables outside the obtained regression model equation.

\section{CONCLUSION}

Based on the research results above, it can be concluded as follows: 1) there is an effect of principal managerial competence on teacher performance at SMA Negeri 5 Palembang. The better the managerial practices done by the principal, the better the teacher's performance; 2) there is an effect of work motivation on teacher performance at SMA Negeri 5 Palembang. The higher the teacher's work motivation, the better the performance is followed, and 3) there is an effect of managerial competence and work motivation on teacher performance at SMA Negeri 5 Palembang. The higher the principal managerial competence and teacher work motivation, the higher the teacher's performance.

\section{ACKNOWLEDGMENT}

Our deepest gratitude goes to Teachers in SMA Negeri 5 Palembang, Chancellor of Palembang PGRI University, Director of the Postgraduate Program of PGRI Palembang University and the Education Management Study Program of PGRI Palembang University, who have supported us in doing this extraordinary thing. This project is funded independently. We also want to thank our Education Management friends who helped us a lot in a short time frame to complete this project.

\section{REFERENCES}

[1] Wahjosumidjo. (2010). Kepemimpinan Kepala Sekolah [Principal Leadership]. Jakarta: Raja Grafindo Persada.

[2] Kristiawan, M. et al. (2017). Manajemen Pendidikan [Education Management]. Yogyakarta: Deepublish.
[3] Yamin, M. dkk. (2010). Standarisasi Kinerja Guru [Teacher Performance Standards]. Jakarta: Gaung Persada.

[4] Yusak, B. (2010). Administrasi Pendidikan [Education administration]. Bandung: Pustaka Setia.

[5] Darmiati, D., Kristiawan, M., \& Rohana, R. (2020). The Influence of School Leadership and Work Motivation toward Teacher's Discipline. Journal of Social Work and Science Education, 1(1), 32-44. Retrieved

from https://ejournal.karinosseff.org/index.php/jswse/arti cle/view/8

[6] Danim, S. (2010). Visi Baru Manajemen Sekolah: dari Unit Birokrasi ke Lembaga Akademik [New Vision of School Management: from Bureaucratic Unit to Academic Institution]. Jakarta: Bumi Aksara.

[7] Direktorat Tenaga Kependidikan. (2008). Penilaian Kinerja Guru [Teacher Performance Appraisal]. Jakarta: Dirjen PMPTK

[8] Kristiawan, M., \& Elnanda, D. (2017). The Implementation of Authentic Assessment in Cultural History of Islamic Subject. Al-Ta lim Journal, 24(3), 266-276.

[9] Herlina, T., Ahmad, S., \& Wahidy. A. (2020). Kemampuan Kepala Sekolah dalam Membina Hubungan dengan Guru Untuk Meningkatkan Mutu Pendidikan [The Principal's Ability in Fostering Relationships with Teachers to Improve the Quality of Education]. Journal of Education Research, Vol 1, No 3. DOI: https://doi.org/10.37985/jer.v1i3.36

[10] Astuti, P., Fitria, H., \& Fitrianti, Y. (2020). Pengaruh Kepemimpinan Kepala Sekolah dan Motivasi Kerja terhadap Kinerja Pegawai [The Influence of Principal Leadership and Work Motivation on Employee Performance]. Jurnal Pendidikan Tambusi Universitas Pahlawan Vol. 4 No.3: //jptam.org/index.php/jptam/article/view/867. https://doi.org/10.31004/jptam.v4i3.867 